\title{
MUDANÇAS POSSIVELMENTE ANTRÓPICAS NA COBERTURA VAGETAL NA REGIÃO DE BÚZIOS, RIO DE JANEIRO, IDENTIFICADAS ATRAVÉS DE ANÁLISES DE FITÓLITOS
}

\author{
Possibly anthropogenic changes in vegetation cover in Búzios, Rio de Janeiro, \\ identified through analysis of phytoliths
}

Heloisa Helena Gomes Coe Professora Ajunta do Departamento de Geografia da UERJ/FFP heloisacoe@yahoo.com

Karina Ferreira Chueng Graduanda de Licenciatura em Geografia da UERJ/FFP, Bolsista PIBIC da UERJ karinachueng@yahoo.com.br

Jenifer Garcia Gomes Graduanda de Licenciatura em Geografia da UERJ/FFP, Bolsista PIBIC da UERJ jenifergg16@hotmail.com

Artigo recebido em 26/05/2012 e aceito para publicação em 20/09/2012

RESUMO: Com a finalidade de contribuir para a reconstituição paleoambiental da região de Búzios, RJ, foram escolhidos como indicadores de possíveis mudanças da vegetação os fitólitos, partículas de sílica amorfa que se acumulam em torno ou dentro das células vegetais. Foram analisadas amostras de um argissolo localizado no bairro de Tucuns, denominação vulgar de palmeiras que devem ter sido abundantes no local, mas que no presente quase não são mais encontradas, sendo a vegetação atual uma mata xeromórfica muito seca com predominância de cactáceas. Entretanto, entre os fitólitos presentes no solo predominam os de palmeiras. Como não há registro, no período de tempo estudado (5.800 anos), de climas mais úmidos, a diminuição da cobertura de palmeiras tem provavelmente origem antrópica, mostrando ser possível relacionar os resultados das análises fitolíticas com o histórico de ocupação e degradação da região.

Palavras-chave: Fitólitos; Búzios, Reconstituição da vegetação; Ação antrópica

ABSTRACT: In order to contribute to the paleoenvironmental reconstruction of the region of Búzios, RJ, phytoliths were chosen as proxy to infer possible changes in the vegetation. Phytoliths are amorphous silica particles that accumulate around or inside the plant cells. Samples were taken from a soil located in the district of Tucuns, popular denomination of palms that must have been abundant at the site, but almost no longer found nowadays, the current vegetation being a very dry forest with a predominance of Cactaceae. However, palm tree phytoliths predominate in the soil. As there is no record of more humid climates during the study period (5800 years), the decrease in palm tree cover is probably anthropogenic, showing to be possible to relate the phytolith results with the history of occupation and degradation of the region.

Key words: Phytoliths, Búzios, Vegetation reconstruction; Anthropogenic action 


\section{INTRODUÇÃO}

Grande parte das formações vegetais primárias do Brasil não pode ser explicada apenas pelas atuais condições climáticas e edáficas, sendo por vezes necessários estudos paleoambientais para compreendê-las. No Estado do Rio de Janeiro, a Região dos Lagos apresenta um clima mais seco que o restante do litoral fluminense, o que determina um panorama peculiar em termos de cobertura vegetal: é considerada como um "enclave fitogeográfico", reduto de vegetação com fisionomia semelhante à da caatinga (AB'SABER, 2003), dominada por florestas xeromórficas, com abundância de Cactaceae e Bromeliaceae, rodeada por florestas úmidas da Mata Atlântica. Esta região foi considerada como um testemunho paleoclimático do clima seco e frio do último Período do Quaternário, tendo sido postulado que a área de caatinga antes ocupava um espaço muito maior, permanecendo, em alguns locais, desde então, como mini ou meso-redutos. (AB'SABER, 1977).

Este estudo foi parte de uma tese de doutorado (COE, 2009), que teve como objetivo auxiliar na reconstituição paleoambiental da Região dos Lagos, o que, até então, vinha sendo feito através de análises de testemunhos oceânicos e lagunares. Estudos da parte continental, que pudessem ser comparados com outras reconstituições, não haviam sido realizados, por falta de indicadores de vegetação que se preservem bem em ambiente oxidante, já que a região carece de lagos adequados à coleta de testemunhos para, por exemplo, análises polínicas. Foram, então, escolhidos como indicadores de possíveis mudanças na vegetação xeromórfica de Búzios os fitólitos, que são partículas de sílica amorfa que se acumulam em torno ou dentro das células vegetais, sendo bem preservadas em solos e paleossolos.

Foram analisadas amostras de quatro perfis de solo, todos localizados no município de Búzios. Neste trabalho apresentaremos os resultados obtidos com um deles, situado no bairro de Tucuns, cujo nome é a denominação vulgar da palmeira Arecacea Astrocarium sp, que deve ter sido abundante no local. Entretanto, a atual cobertura vegetal do perfil é caracterizada pela presença de uma floresta xeromórfica muito seca (caatinga hipoxerófila), com predominância de cactáceas e as palmeiras tucuns quase não são mais encontradas nas proximidades do perfil, sendo observados alguns exemplares apenas nas partes mais elevadas da região. Este fato pode indicar uma degradação da região, provavelmente de origem antrópica.

\section{FUNDAMENTAÇÃO TEÓRICO METODOLÓGICA}

Fitólitos são partículas de opala $\left(\mathrm{SiO}_{2} \mathrm{nH}_{2} \mathrm{O}\right)$ microscópicas $(<60-100 \mu \mathrm{m})$ que se formam por precipitação de sílica amorfa entre e nas células de diversas plantas vivas (PIPERNO, 1988). Resultam de um processo de biomineralização onde as plantas constroem uma estrutura ou molde onde se introduzem os íons e ali são induzidos a se precipitar e cristalizar (OSTERRIETH, 2008).

Desta forma, a forma dos fitólitos recorda a célula em que foi formado, que funciona como um "molde". Algumas famílias de plantas produzem fitólitos morfologicamente distintivos, como as dicotiledôneas lenhosas (globular granulate), as palmeiras (globular echinate), as ciperáceas (cone shape) e principalmente as gramíneas, que são as maiores produtoras e onde a distinção pode chegar ao nível de subfamília. A subfamília Panicoideae, característica de ambientes quentes e úmidos, produz principalmente fitólitos de tipo bilobate e polylobate. A sub-família Chloridoideae, característica de ambientes quentes e secos, produz principalmente 
fitólitos de tipo saddle, enquanto a sub-família Pooideae, característica de regiões temperadas, frias e altas elevações intertropicais, produz principalmente fitólitos de tipo rondel (figura 1).

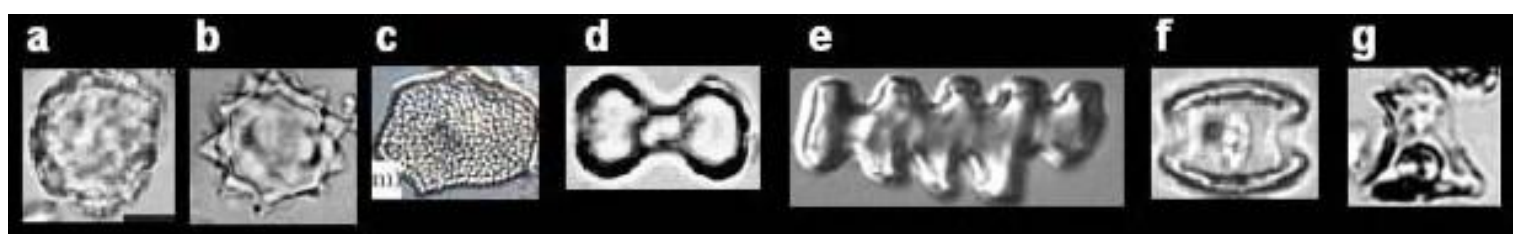

Figura 1: tipos de fitólitos a) globular granulate; b) globular echinate; c) cone shape; d) bilobate; e) polylobate; f) saddle; g) rondel

(Fonte: Barboni et al., 1999)

Os fitólitos são utilizados para documentação e reconstrução ambiental. A análise de uma assembléia fitolítica permite caracterizar uma formação vegetal. Estudam-se assembléias de fitólitos modernas e fósseis, calculam-se índices fitolíticos, verificando-se se as sequências fitolíticas nos solos, resultantes dos processos de acumulação e/ou erosão, de translocação e de dissolução, mostram um aumento da idade média das partículas com a profundidade e podem, portanto, ser interpretadas em termos paleoambientais.

Os índices fitolíticos permitem inferir parâmetros de vegetação como a densidade da cobertura arbórea (D/P - Dicotiledôneas/Poaceae), densidade de palmeiras ( $\mathrm{Pa} / \mathrm{P}$ Palmeiras/Poaceae), a proporção de gramíneas C3 ou C4 (Ic - Índice climático); altas ou baixas (Iph - Index of phytoliths), e a adaptação das mesmas ao estresse hídrico ( $\mathrm{Bi}$ - Bulliform index).

As calibrações entre assembléias fitolíticas, fisionomia das vegetações e limites climáticos mostram que os fitólitos são marcadores fiáveis e precisos das vegetações intertropicais e principalmente das diferentes formações herbáceas. A diversidade das formações herbáceas tropicais é o reflexo de uma diversidade climática, edáfica e antrópica que podem ser melhor compreendidas através das reconstituições fitolíticas (BREMOND et al., 2005).

\section{ÁREA DE ESTUDOS}

A área estudada localiza-se no bairro de Tucuns, no município de Armação dos Búzios, RJ, parte do litoral fluminense conhecida como Região dos Lagos. A Região dos Lagos abrange os municípios de Arraial do Cabo, Búzios, Cabo Frio, Iguaba, São Pedro da Aldeia e Araruama, com uma área de aproximadamente $1.500 \mathrm{~km}^{2}$ e está localizada entre as coordenadas $22^{\circ} 30^{\prime}$ $23^{\circ} 00^{\prime} \mathrm{S}$ e $41^{\circ} 52^{\prime}-42^{\circ} 42^{\prime} \mathrm{W}$ (figura 2 ).

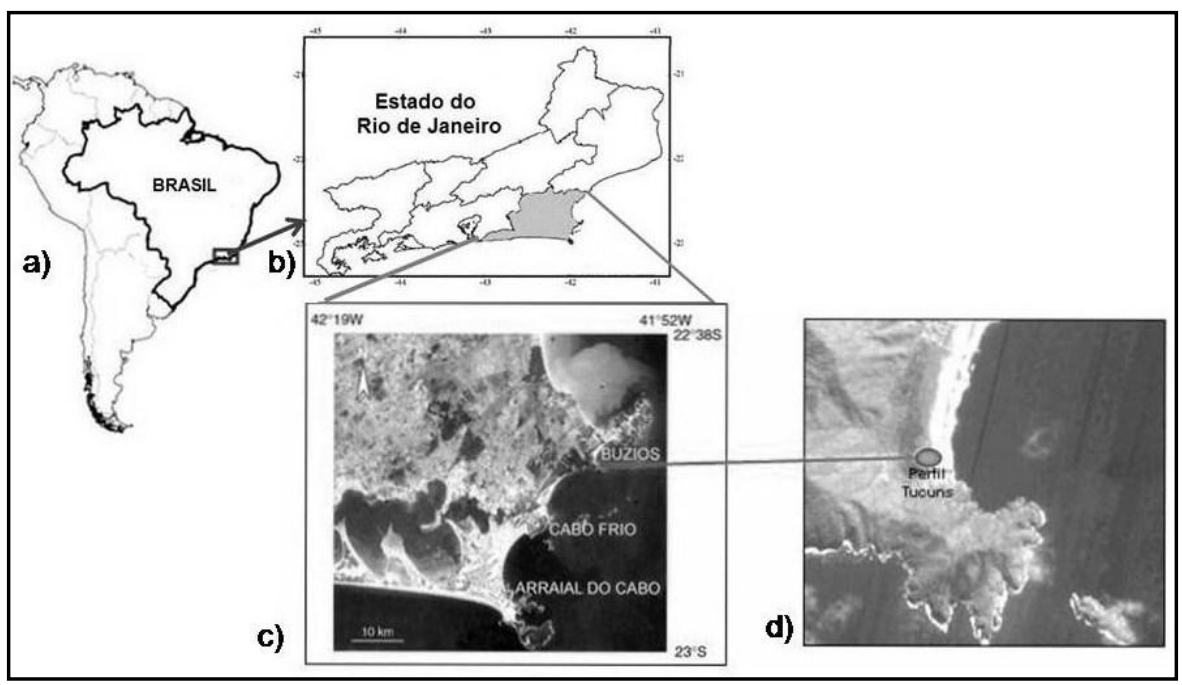

Figura 2: Localização da área de estudo: a) no Brasil; b) no Estado do Rio de Janeiro; c) Região dos Lagos; d) perfil de solo Tucuns (Fonte: Coe, 2009) 
A área apresenta uma série de peculiaridades climáticas, geológicas e ecológicas que condicionam diversas formações vegetais, com muitas espécies endêmicas e raras. De todos os fatores físicos, o clima parece ser o elemento que exerce maior influência sobre os ecossistemas locais. Esta região apresenta um clima mais seco que o restante do litoral fluminense (854 $\mathrm{mm} / \mathrm{ano}$ ), relacionado, entre outros fatores, à grande distância da linha de costa até a Serra do Mar e à presença de uma ressurgência costeira intermitente, intensificada pelos fortes ventos de NE. Esta ressurgência leva a uma redução na precipitação e, consequentemente, a um aumento na evaporação e salinidade das lagoas.

A região apresenta um complexo quadro geológico e geomorfológico, cuja litologia é composta principalmente por paragnaisses originados de depósitos marinhos pelíticos, muito antigos e intemperizados, areias e materiais argilosos que formam espessos mantos de alteração, onde concreções ferruginosas e linhas de pedra podem ser encontradas. É caracterizada por grandes lagoas de água salgada ou salobra que foram isoladas do oceano por longos pontais distanciados do litoral, em grande parte, modeladas pelas variações do nível relativo do mar durante o Quaternário.

Os solos são pouco desenvolvidos, normalmente rasos, com características morfológicas, químicas e mineralógicas que sugerem um regime pedogenético particular. Apresentam considerável variabilidade vertical e horizontal, sendo fortemente influenciados por fatores climáticos e topográficos. Os solos sob caatinga hipoxerófila constituem tanto o substrato fundamental a esse ambiente sui generis, quanto à possibilidade de representarem pedoambientes outrora mais amplos e hoje isolados, mantidos graça às peculiaridades morfoclimáticas regionais (IBRAIMO et al., 2004).

\section{MATERIAIS}

Foram utilizadas quatro amostras coletadas em cada um dos horizontes (A1: de 0 a $25 \mathrm{~cm}$ de profundidade, A2: de 25 a $50 \mathrm{~cm}$ de profundidade, B: de 50 a $80 \mathrm{~cm}$ de profundidade, BC: de 80 a $122 \mathrm{~cm}$ de profundidade) de um perfil de solo de tipo "argissolo amarelo eutrófico abrúptico chernossólico textura média/ argilosa relevo forte ondulado", localizado a $22^{\circ} 48^{\prime 2} 22,6$ "S / $41^{\circ} 55^{\prime} 50,4^{\prime \prime} \mathrm{W}$ na Praia de Tucuns, Búzios, RJ (figura 2b), no terço inferior da encosta, a $20 \mathrm{~m}$ de altitude (figura 3 ).

a)

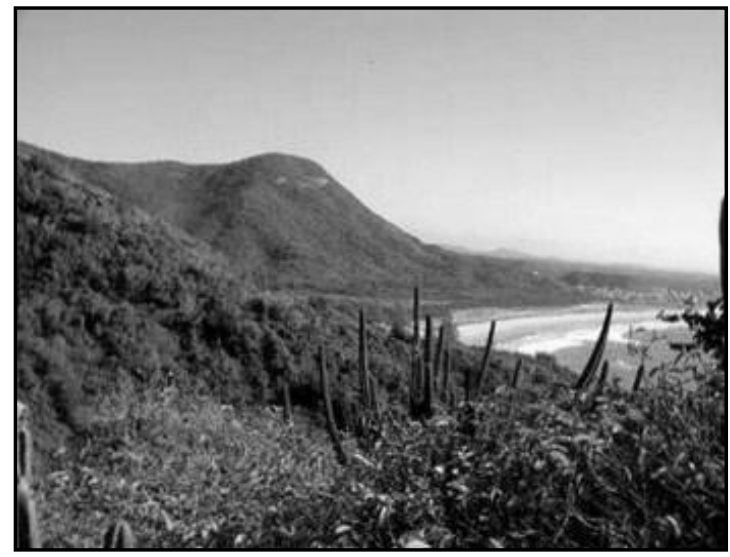

b)

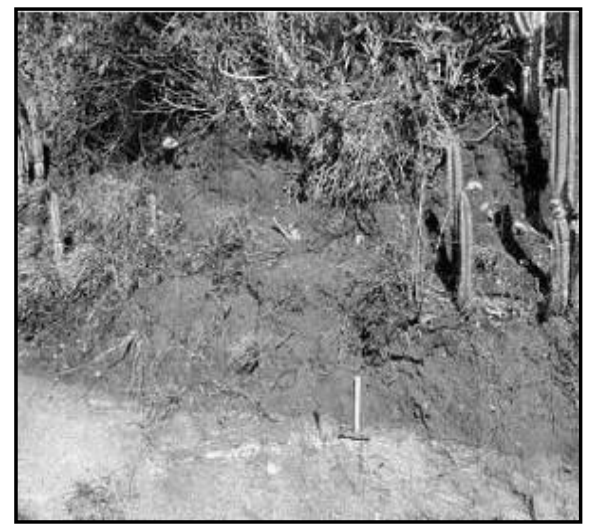

Figura 3: Perfil Tucuns: a) localização na encosta; b) detalhes do perfil 
A atual cobertura vegetal do perfil é caracterizada pela presença de uma floresta xeromórfica muito seca (caatinga hipoxerófila), muito influenciada pela vegetação de restinga, com predominância da espécie endêmica Cactaceae Pilosocereus ulei (figura 4).

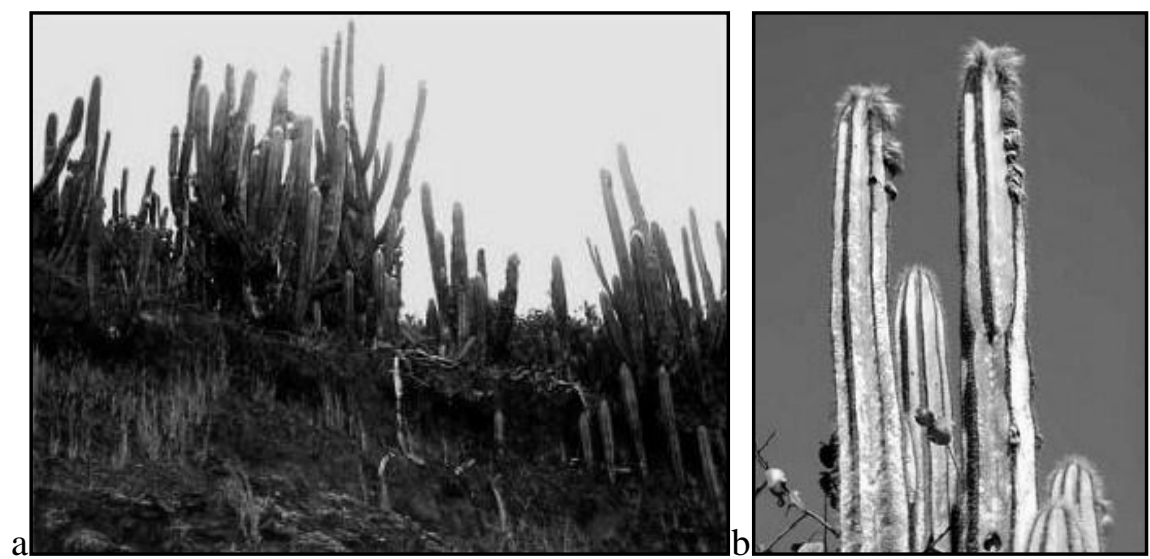

Figura 4: Cobertura atual do perfil: a) Caatinga hipoxerófila; b) Cactaceae Pilosocereus ulei

As espécies arbóreas mais comuns são Anacardiaceae (em grande quantidade), Apocinaceae, Ericaceae, Bombacaceae, Euphorbiaceae, Clusiaceae e algumas Bignoniaceae. O sub-bosque é constituído por muitas Bromeliaceae, além de Araceae, Iridaceae e uma espécie de Arecaceae, o buriri (figura 5). Não há Poaceae acima do perfil, somente algumas Panicoideae invasoras na beira da estrada.
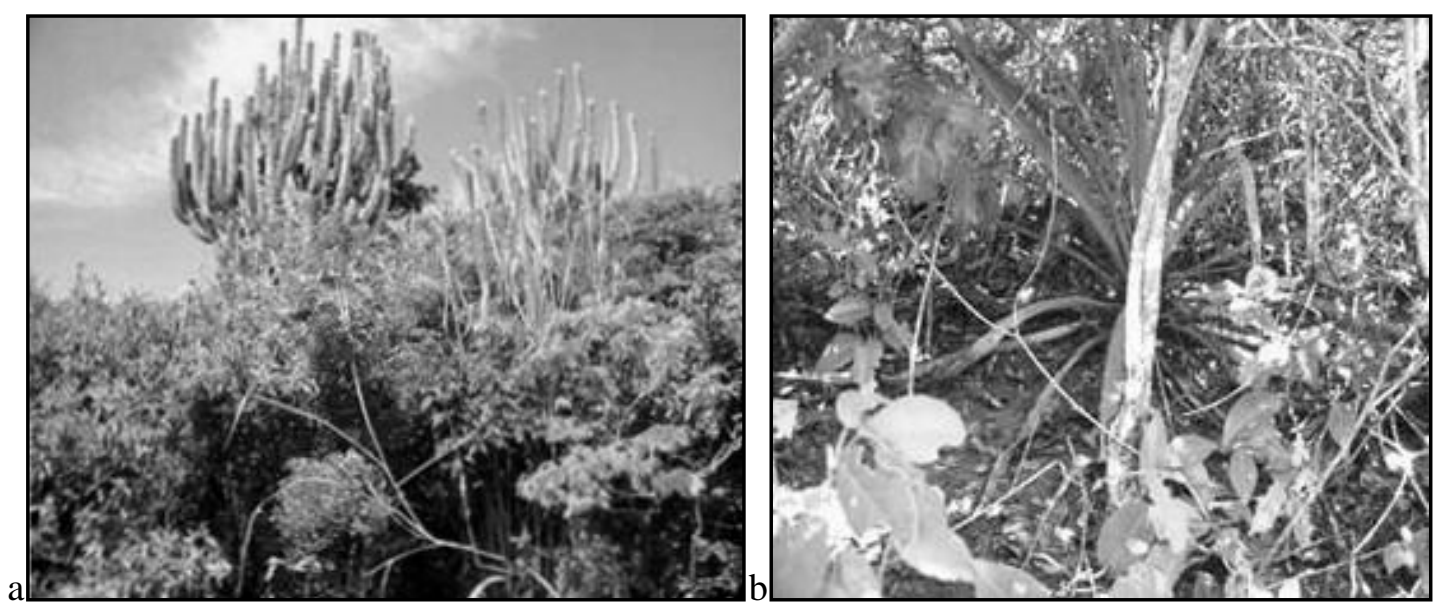

Figura 5: Espécies vegetais sobre o perfil: a) estrato arbóreo; b) sub-bosque

\section{MÉTODOS}

\section{Fitólitos:}

Extração e quantificação de fitólitos de solo: a preparação inicial consistiu em secar e peneirar a $2 \mathrm{~mm}$ as amostras, obtendo-se $20 \mathrm{~g}$ de solo. Em seguida, foi feita a dissolução dos carbonatos com $\mathrm{HCl}(3 \%)$ e a oxidação total da matéria orgânica com peróxido de hidrogênio (30\%) aquecida em banho de areia a $90^{\circ} \mathrm{C}$. Passou-se à fase de solubilização do Ferro com Citrato de Sódio a 88,4g/l e Diotinito de Sódio e à remoção das argilas por sedimentação. A fração de 2$60 \mu \mathrm{m}$ foi então submetida à separação densimétrica em líquido denso $(\mathrm{d}=2,3)$ composto de 
Brometo de Zinco diluído em Ácido Clorídrico. As partículas foram em seguida secas em estufa e pesadas para se calcular o teor de fitólitos em cada amostra.

Taxonomia e Contagem: as observações foram feitas em microscópio óptico, com aumento de 600x. Pelo menos 200 fitólitos com significação taxonômica (classified phytoliths) foram contados levando-se em consideração sua forma original, bem como sua subsequente dissolução ou fragmentação. Também foram contados os fitólitos sem significação taxonômica (unclassified phytoliths), partículas em que, apesar de serem certamente fitólitos, não se pode mais distinguir a forma original. As assembléias fitolíticas foram apresentadas como a soma de fitólitos classificados e não classificados. Foram também contadas todas as partículas da lâmina que não são fitólitos. Foi também observado o grau de alteração dos fitólitos, contado em fitólitos do tipo bulliform. Os fitólitos foram classificados de acordo com a classificação de Twiss et al. (1969) e Twiss (1992), aumentada por Mulholland (1989), Fredlund \& Tieszen (1994), Kondo et al.(1994), Alexandre et al. (1997) e Barboni et al. (1999), seguindo a nomenclatura do ICPN (2005).

Índices fitolíticos: foram calculados os seguintes índices:

a) D/P (Dicotiledôneas lenhosas / Poaceae): é a proporção de fitólitos característicos dos elementos lenhosos em relação à soma de fitólitos de gramíneas. Este índice indica a densidade da cobertura arbórea. Calcula-se: $\mathrm{D} / \mathrm{P}=$ Globular granulate / (bilobate short cell + cross + saddle + bulliform $)$

b) Pa/P (Palmeiras / Poaceae): é a proporção de fitólitos característicos de palmeiras em relação à soma de fitólitos de gramíneas. Este índice indica a densidade da cobertura por palmeiras. Calcula-se: $\mathrm{Pa} / \mathrm{P}=$ globular echinate $/($ short cells + bulliform + acicular $)$

c) Bi\%: é a proporção do morfotipo bulliform em relação ao total de fitólitos de gramíneas. Este índice indica a abundância relativa de fitólitos buliform que se precipitam na epiderme das gramíneas quando elas são submetidas a um forte estresse hídrico. Permite estimar a aridez do ambiente, é um indicador de estresse hídrico. Calcula-se: Bi \% = Bulliform / [(short cells + acicular + bulliform)] x 100

Análises fisico-químicas: foram realizadas, na Embrapa-solos, análises físico-químicas de

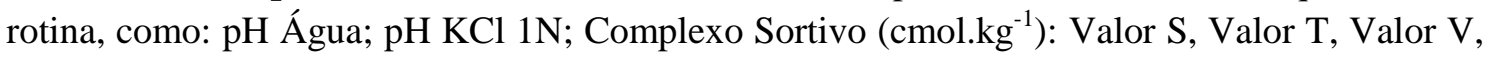
$\mathrm{P}(\mathrm{mg} / \mathrm{kg}), \mathrm{Ca}^{2}, \mathrm{Mg}^{2+}, \mathrm{K}^{+}, \mathrm{Na}^{+}, \mathrm{Al}^{3+}, \mathrm{H}^{+}$Relações moleculares: $\mathrm{Al}_{2} \mathrm{O}_{3} / \mathrm{Fe}_{2} \mathrm{O}_{3}, \mathrm{Ki}, \mathrm{Kr}$; Sílica amorfa: $\mathrm{Si}(\mathrm{g} / \mathrm{kg}), \mathrm{SiO} 2(\mathrm{~g} / \mathrm{kg})$; Óxidos $(\mathrm{g} / \mathrm{kg}): \mathrm{SiO}_{2}, \mathrm{Al}_{2} \mathrm{O}_{3}, \mathrm{Fe}_{2} \mathrm{O}_{3}, \mathrm{TiO}_{2}, \mathrm{P}_{2} \mathrm{O}_{5}$; Sais solúveis $\left(\mathrm{cmol} . \mathrm{kg}^{-1}\right): \mathrm{K}^{+}, \mathrm{Na}^{+} ; 100 . \mathrm{Al}^{3+} \mathrm{S}+\mathrm{Al}^{3+}(\%), 100 . \mathrm{Na}^{+} / \mathrm{T}(\%)$; C.E. do extrato $\mathrm{mS} / \mathrm{cm} 25^{\circ} \mathrm{C}$; Água $\%$; Densidade aparente $\left(\mathrm{g} . \mathrm{cm}^{-3}\right)$; Granulometria: porcentagens de Argila, Areia grossa, Areia Fina e Silte; razões AF/AG, Silte/argila; média phi das 5 frações de areia.

Análises da composição elementar, isotópica e molecular da matéria orgânica: foram realizadas nos laboratórios do CENA/USP, análises dos teores em Carbono, Nitrogênio, razão $\mathrm{C} / \mathrm{N}, \delta^{13} \mathrm{C}$ e $\delta^{15} \mathrm{~N}$. Nos laboratórios do Departamento de Geoquímica da UFF foram feitas análises das ligninas: totais, grupos de fenóis, índice de degradação.

Datações da Matéria Orgânica do Solo (MOS): foram datadas duas amostras, uma na base $\left(101 \mathrm{~cm}\right.$ de profundidade) e a outra no topo $(12,5 \mathrm{~cm})$ do perfil, através do ${ }^{14} \mathrm{C}$ da MOS, por AMS, nos laboratórios da Universidade de Irvine, Califórnia. 


\section{RESULTADOS}

\section{Fitólitos}

Quantificação do estoque em fitólitos com a profundidade: os estoques em fitólitos apresentam uma diminuição exponencial com a profundidade, variando de 0,77 (no topo) a 0,10 \% (no horizonte BC), segundo a mesma tendência do Carbono orgânico (figura 6a).

Morfotipos de fitólitos: entre os fitólitos classificados, foram encontrados principalmente os tipos bulliform e globular echinate; os tipos globular granulate, elongate e unknown são pouco representativos. Entre os morfotipos de Poaceae, foram identificados muito poucos short cells, dos quais a maioria do tipo saddle. As maiores variações dos morfotipos ao longo do perfil são observadas entre A2 e B (aumento dos bulliform e diminuição dos echinate). (figura 6a)

Grau de alteração dos fitólitos do tipo bulliform: a intensidade das marcas de alteração dos fitólitos aumenta com a profundidade. Primeiramente há uma pequena redução nos horizontes A2 e B, seguida de um aumento da alteração no horizonte BC (figura 6a).

Índices fitolíticos: o índice D/P é sempre muito baixo, variando entre 0,1 e 0,2. Para este perfil o índice $\mathrm{Pa} / \mathrm{P}$ é mais representativo tendo sido utilizado para delimitar zonas, variando de 0,7 a 0,5 nos horizontes A, diminuindo para 0,08 em B e nem sendo significativo em BC. O índice Bi é sempre muito elevado, com grandes variações (amplitude de 9 a 12\%) entre os horizontes A1, A2 e B e pequena (2\%) entre B e BC (figura 6b).

\section{Composição molecular: ligninas}

Totais de ligninas: o total de ligninas foi calculado em $\mathrm{mg} / 100 \mathrm{mg} \mathrm{CO}$ (carbono orgânico) e em $\mathrm{mg} / 10 \mathrm{~g}$ PS (peso seco). O perfil mostra tendência de decréscimo gradual com a profundidade, sem exceções (figura 6b).

Grupos de fenóis vanilil, siringil e cinamil: três grupos de fenóis das ligninas são encontrados exclusivamente em plantas superiores e são indicativos de aporte de MO de origem terrestre: vanilina (V), siringil (S), de plantas lenhosas e cinamil (C), de não lenhosas (KILLOPS \& KILLOPS, 2005). No perfil, o grupo V sempre predomina, com maior diferença em relação ao $\mathrm{S}$ no horizonte $\mathrm{B}$ e os 2 grupos se igualam no horizonte BC (figura $6 \mathrm{~b}$ ).

Índice de degradação das ligninas (Ad/Al)V: apesar de lignino-fenóis serem relativamente de baixa degradação, alguns tipos de fungos e bactérias são capazes de quebrar suas moléculas (KILLOPS \& KILLOPS, 2005). Razões [(Ad/Al)V] superiores a 0,4 são indicativos de que esse material já está sofrendo processos de degradação. A tendência é o aumento da degradação das ligninas com a profundidade, pois se espera que o material seja mais antigo. Esta tendência foi confirmada no perfil (figura $6 \mathrm{~b}$ ).

\section{Composição elementar da matéria orgânica}

Carbono: os teores em Carbono variaram de 1,4\% no horizonte superficial e decresceram com a profundidade até $0,6 \%$, seguindo a tendência normal de distribuição do carbono no solo (ALEXANDRE et al., 1997) (figura 6c). 
Nitrogênio: a tendência do teor em Nitrogênio é diminuir com a profundidade, acompanhando os teores de carbono. Menores teores de Nitrogênio podem significar maior degradação (maior exposição à luz, oxigênio, maior atividade bacteriana). O perfil (figura 6c) apresenta diminuição gradual do teor em $\mathrm{N}$ com a profundidade.

Razão C/N: a razão C/N é um indicador que permite avaliar o grau de evolução da MO, ou seja, sua capacidade de se decompor mais ou menos rapidamente no solo. Quando o $\mathrm{C} / \mathrm{N}$ é menor que 15 , há liberação de $\mathrm{N}$, a velocidade de decomposição aumenta, atingindo o máximo quando $\mathrm{C} / \mathrm{N}$ é igual a 10. Quanto maior o $\mathrm{C} / \mathrm{N}$, mais lentamente a decomposição ocorre no solo, entretanto o húmus obtido é mais estável. No perfil (figura 6c), os valores de $\mathrm{C} / \mathrm{N}$ mostram duas zonas definidas: cerca de 10 nos dois horizontes superficiais e 8,3/8,5 nos mais profundos.

\section{Composições isotópicas da matéria orgânica}

Valores $\delta^{13} \mathbf{C} \%$ : não houve grandes variações nos sinais isotópicos $\delta^{13} \mathrm{C} \%$ em profundidade (figura 6c). Foram encontrados valores com sinais de plantas C3 ou CAM, embora não muito empobrecidos (de $-23,7$ a $-22,3 \%$ ), o que pode representar uma mistura de sinais de plantas $\mathrm{C} 3$, C4 e CAM, com predomínio de plantas C3.

Valores $\delta^{15} \mathrm{~N}$ : os teores em $\delta^{15} \mathrm{~N}$ podem indicar o grau de degradação do nitrogênio. Quanto maior o teor em $\delta^{15} \mathrm{~N}$, mais reciclado é o $\mathrm{N}$, pois a planta usa mais o ${ }^{14} \mathrm{~N}$, que é mais leve. Assim, nos horizontes mais profundos costumam-se observar valores de $\delta^{15} \mathrm{~N}$ maiores, assim como o de $\mathrm{N}$ menor. Apesar de não mostrar grandes variações com a profundidade, essa tendência foi observada no perfil. (figura $6 \mathrm{c}$ )

Análises físico-químicas: a síntese dos resultados de algumas análises físico-químicas é apresentada na figura 6d. Estas análises serviram para confirmar a existência ou não de descontinuidades pedológicas que foram observadas em campo e/ou em outras análises (fitolíticas, orgânicas) e para a identificação de zonas que permitiram o estabelecimento de hipóteses para a evolução do perfil.

Datações da matéria orgânica do solo: a base do perfil data de 5.800 anos AP (idade calibrada) e o topo é de idade moderna. 

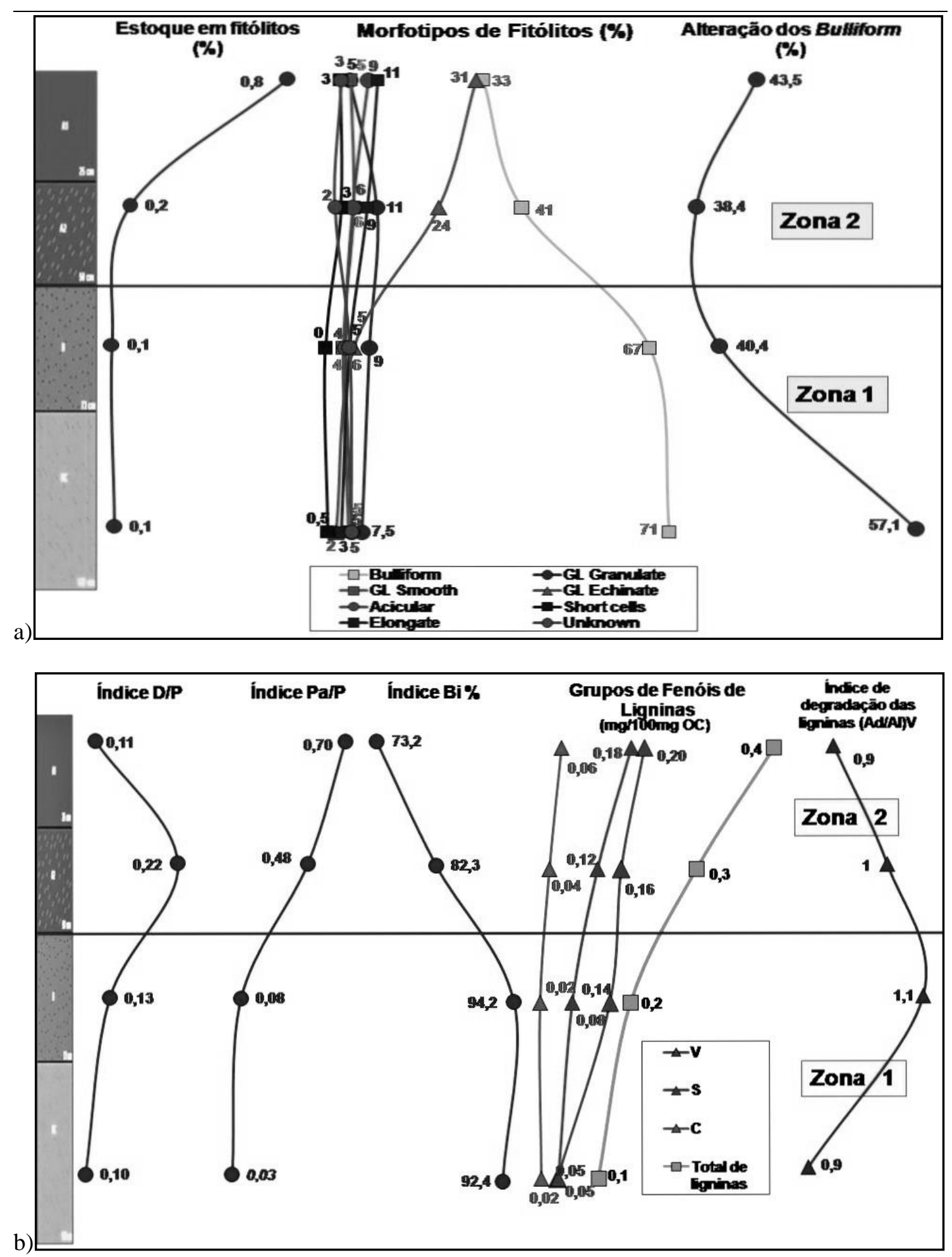

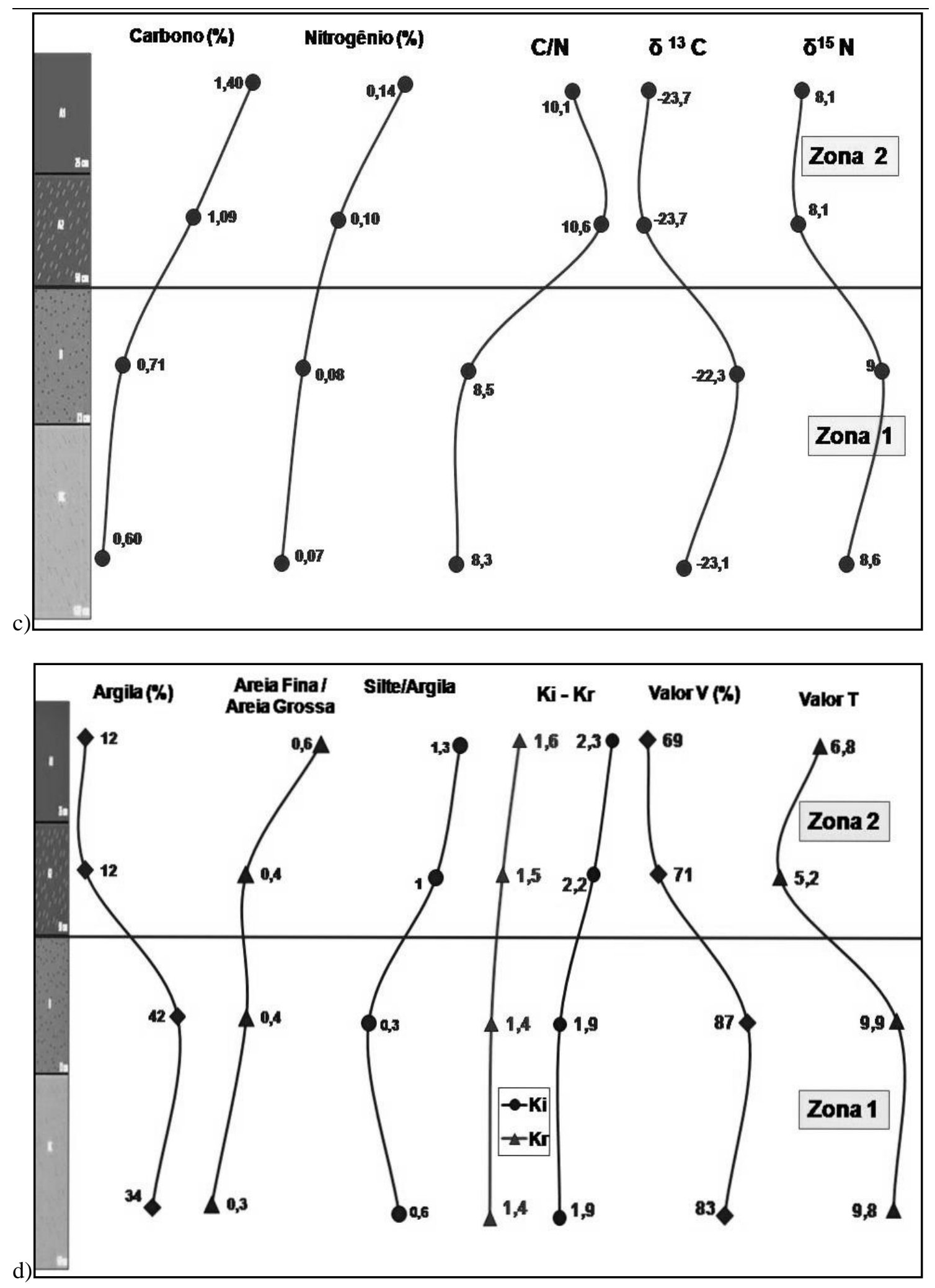

Figura 6: Síntese dos resultados das análises do perfil Tucuns: a) fitólitos; b)índices fitolíticos (D/P= Dicotiledôneas/Poaceae; Pa/P= Palmeiras/Poaceae; $\mathrm{Bi}=$ Bulliform index) e ligninas $(\mathrm{OC}=$ Organic Carbon; $(\mathrm{Ad} / \mathrm{Al}) \mathrm{V}=$ forma Ácida/ forma Aldeídica dos fenóis do grupo Vanilil) (Fonte: Coe, 2009); c) orgânicas elementares e isotópicas; d) físico-químicas (Fonte: Coe, 2009) 


\section{DISCUSSÃO DOS RESULTADOS}

Foram utilizados os resultados das análises fitolíticas (principalmente o índice $\mathrm{Pa} / \mathrm{P}$ e o estoque de fitólitos) para identificar zonas relativamente homogêneas no interior do perfil. Em seguida, para cada uma das zonas fitolíticas, foi verificado se os resultados das outras análises (físico-químicas, isotópicas, orgânicas, ligninas), corroboravam ou discordavam daqueles obtidos com os fitólitos. Dentre os resultados relacionados com a matéria orgânica, aqueles cujas variações mais acompanharam as análises fitolíticas foram os de porcentagem de Carbono e $\mathrm{C} / \mathrm{N}$, os isotópicos $\left(\delta^{13} \mathrm{C}\right.$ e $\left.\delta^{15} \mathrm{~N}\right)$ e de ligninas (total e índice de degradação). Quanto às análises físico-químicas, as mais significativas foram as de granulometria e os valores $\mathrm{V}, \mathrm{T}$ e $\mathrm{S}$. Os resultados das datações da Matéria Orgânica do Solo (MOS) por ${ }^{14} \mathrm{C}$ também foram comparados com alguns outros resultados (alteração dos fitólitos de tipo bulliform, total e índice de degradação das ligninas, $\delta^{15} \mathrm{~N}$ e índice $\mathrm{Kr}$ ) (figura 6).

Toda interpretação de dados fitolíticos em perfis de solo deve verificar se a intensidade das marcas de alteração dos fitólitos de tipo bulliform aumenta com a profundidade. Este aumento da alteração implica em um aumento do tempo de residência das partículas no solo e, portanto, um aumento da idade média dos fitólitos com a profundidade (ALEXANDRE et al., 1997; 1999), o que pode corroborar as datações da MOS obtidas para as mesmas profundidades. Este aumento no grau de alteração dos bulliform com a profundidade foi observado no perfil.

No caso de um solo residual, as distribuições da matéria orgânica e das assembléias fitolíticas seguem um modelo bicompartimentado (ALEXANDRE et al., 1997), com um pólo lábil, formado por partículas mais jovens, que diminuem em proporção com a profundidade e um pólo estável, formado por partículas mais antigas, e que se mantém relativamente constante com a profundidade. Quando um solo é remanejado por eventos de erosão, transporte e coluvionamento, além do material original há o aporte de partículas (jovens e antigas) de outras fontes. Por isso não se pode analisar perfis de solo como uma sequência sedimentar, mas como uma mistura entre materiais de origem e idades diferentes, que sofreram transporte e bioturbação. Além disso, como a reconstituição utiliza datações ${ }^{14} \mathrm{C}$ da MOS, não se podem negligenciar seus movimentos ao longo do perfil mesmo após sua deposição, podendo haver mistura de partículas mais jovens e mais antigas. Assim, cada datação será considerada como a idade média mínima da MOS naquela profundidade, e não será tomada como idade absoluta, apenas servirá para estimar a dinâmica das assembléias fitolíticas no seio de cada perfil de solo.

As análises fitolíticas, pedológicas e orgânicas indicam duas zonas bem distintas no perfil: uma com os horizontes superficiais (A1 e A2) e outra formada pelos mais profundos, horizontes B e BC. Em todas as análises e observações não foram encontradas evidências de eventos erosivos que teriam truncado um antigo desenvolvimento de solo e de uma posterior pedogênese, mais recente. A hipótese mais provável é que o perfil é produto de um único desenvolvimento de solo, que também recebeu aportes por deslizamentos das partes mais altas da vertente, já que ocupa posição topográfica no terço inferior da encosta.

O perfil apresentou uma particularidade: o índice D/P, normalmente utilizado para delimitar zonas fitolíticas, não é significativo e foi substituído por um novo índice, o Pa/P, que indica a abundância de Arecaceae (palmeiras). Entretanto, na vegetação atual as palmeiras não são abundantes, com presença (não dominância) de uma espécie de menor porte, Allagoptera arenaria (nome popular: guriri ou buriri). Além do guriri, são encontradas, apenas nas partes mais elevadas da região (alto da Serra das Emerências), palmeiras da espécie Astrocaryum aculeatissimum (nome popular: tucum), que deu nome à região. 


\section{Hipóteses sobre a evolução do Perfil:}

Os resultados das análises fitolíticas indicam diferenças entre as duas zonas, principalmente no que se refere ao estoque de fitólitos (que sofre o decréscimo normal com a profundidade) e ao índice $\mathrm{Pa} / \mathrm{P}$, que não é significativo na Zona 1 e o mais importante na Zona 2, principalmente no horizonte A1. Estas diferenças apontam uma mudança na cobertura vegetal do perfil, com um aumento importante da presença de palmeiras nos tempos atuais. Entretanto, como os sinais fitolíticos na Zona 1 são fracos, é difícil definir a vegetação sobre a mesma.

Desta forma, há duas hipóteses para a evolução do perfil:

\section{Hipótese I:}

- Na Zona 1 (5.800 anos cal BP na base do perfil a 101 $\mathrm{cm}$ de profundidade), as assembléias fitolíticas traçam a antiga vegetação sobre o perfil. A vegetação sobre a Zona 1 era diferente da atual, sobrejacente à Zona 2, mas não é possível defini-la.

- Na Zona 2 (idade "moderna" no topo do perfil a 12,5cm de profundidade), as assembléias fitolíticas são o resultado de mistura entre a vegetação original da parte erodida (partes mais elevadas da encosta onde se localiza o perfil), com a vegetação mais recente sobre o perfil. Os sinais fitolíticos (índice $\mathrm{Pa} / \mathrm{P}$ ) indicam uma vegetação com predomínio de palmeiras.

\section{Hipótese II:}

- Os fitólitos residuais da Zona 1 seriam uma mistura da assembléia original (que teriam sofrido dissolução seletiva elou translocação preferencial dos bulliform) com o aporte da translocação de fitólitos da Zona 2, em equilíbrio com a vegetação atual.

- Na Zona 2, as assembléias fitolíticas são o resultado de mistura entre a vegetação original da parte erodida do alto da encosta, com a vegetação mais recente sobre o perfil.

Apesar dos resultados do índice $\mathrm{Pa} / \mathrm{P}$ indicarem um aumento da cobertura por palmeiras num período mais recente da evolução do perfil, esta não é a vegetação existente atualmente na área estudada. Podemos, então, formular as seguintes hipóteses sobre a presença e evolução das palmeiras em Tucuns:

1- As assembléias fitolíticas registram a presença de palmeiras (provavelmente da espécie tucum, devido ao nome do lugar) sobre o perfil, num período anterior ao de maior ocupação humana na região. Nesse caso, os fitólitos marcariam modificações antrópicas relativamente recentes na vegetação.

2- As palmeiras tucuns se concentravam nas partes mais elevadas (topo da serra) e as assembléias fitolíticas seriam o resultado de mistura entre o aporte da vegetação original da parte erodida do alto da encosta com a vegetação mais recente sobre o perfil.

3- Podem ter ocorrido ambas as hipóteses: aporte de fitólitos da vegetação do alto da vertente e modificações antrópicas recentes, que teriam reduzido a presença de palmeiras na região, ficando hoje restrita às áreas mais preservadas, de acesso mais difícil à ocupação humana, como o topo das encostas.

\section{CONSIDERAÇÕES FINAIS}

Esta pesquisa pretendeu auxiliar na reconstituição paleoambiental da Região dos Lagos, onde ainda existem grandes lacunas, devido à falta de indicadores adequados, tendo por isso sido utilizadas as análises de fitólitos em amostras de quatro perfis de solo. Em todos eles, as variações observadas não indicam uma grande mudança no tipo de cobertura vegetal, que 
sempre se caracteriza como pouco arbórea (floresta xeromórfica), sugerindo que, pelo menos dentro do período de tempo estudado, a vegetação local nunca atingiu a densidade arbórea característica de florestas úmidas do restante do litoral fluminense. Quanto ao perfil Tucuns, apesar das mudanças na sua cobertura vegetal com a presença de palmeiras, também não houve registro de tipos de vegetação característicos de clima úmido.

Apesar de algumas incertezas, as assembléias fitolíticas registraram mudanças na vegetação que podem ter origem antrópica, numa escala de tempo "humana", não geológica, sendo então possível relacionar os resultados com o histórico de ocupação e degradação da região. Para isso, é necessário o aprofundamento e a continuidade da pesquisa, tanto no que se refere às análises fitolíticas, quanto à ecologia da palmeira Astrocaryum aculeatissimum (tucum), além da realização de um levantamento sobre o histórico da ocupação da região de Búzios.

\section{AGRADECIMENTOS}

À Capes, pela concessão da bolsa de estágio doutoral no exterior, à FAPERJ, pelo suporte financeiro, à Dra. Guaciara dos Santos, da Universidade de Irvine, Califórnia, pelas datações ${ }^{14} \mathrm{C}$ e ao Dr. Marcelo Bernardes, da Universidade Federal Fluminense, pelas análises de ligninas e ao Dr. Luiz Carlos Pessenda do CENA/USP, pelas discussões esclarecedoras sobre as análises isotópicas.

\section{REFERÊNCIAS BIBLIOGRÁFICAS}

AB'SABER, A. N. Espaços ocupados pela expansão dos climas secos na América do Sul por ocasião dos períodos glaciais quaternários. Paleoclimas, v.3, p.1-19. 1977.

AB'SABER, A. N. Redutos de cactáceas, jardins da natureza. Scientific American Brasil, v.19, dez. 2003.

ALEXANDRE, A., MEUNIER, J. D., COLIN, F., KOUD, J. M. Plant impact on the biogeochemical cycle of silicon and related weathering processes. Geochimica et Cosmochimica Acta, v.61, n.3, 1997/2, p.677-682. 1997.

ALEXANDRE, A., J. D. MEUNIER, COLIN, F., KOUD, J. M. Late Holocene Phytolith and Carbon-Isotope Record from a Latosol at Salitre, South-Central Brazil. Quaternary Research, v.51, n.2, 1999/3, p.187-194. 1999.

BARBONI, D., BONNEFILLE, R., ALEXANDRE, A., MEUNIER, J.D. Phytoliths as paleoenvironmental indicators, West Side Middle Awash Valley, Ethiopia. Palaeogeography, Palaeoclimatology, Palaeoecology. 152, 87-100, 1999.

BARBONI, D.; BREMOND, L.; BONNEFILLE, R. Comparative study of modern phytolith assemblages from inter-tropical Africa. Palaeogeography, Palaeoclimatology, Palaeoecology, v.246, p.454-470. 2007.

BREMOND, L., ALEXANDRE, A., PEYRON, O., GUIOT, J. Grass water stress estimated from phytoliths in West Africa. Journal of Biogeography, v.32, p.311-327. 2005. 
COE, H. H. G. Fitólitos como indicadores de mudanças na vegetação xeromórfica da região de Búzios/Cabo Frio, RJ, durante o Quaternário. 300 p. Tese de Doutorado em Geologia Marinha, Universidade Federal Fluminense, Niterói, 2009.

FREDLUND, G. G., TIESZEN, L. L. Modern phytolith assemblages from the North American Great Plains. J. Biogeogr. 21, 321-335, 1994.

IBRAIMO, M. M., SCHAEFER, C. E. G. R., KER, J. C., LANI, J. L., ROLIM-NETO, F. C., ALBUQUERQUE, M. A., MIRANDA, V. J. Gênese e Micromorfologia de Solos sob Vegetação Xeromórfica (caatinga) na Região dos Lagos (RJ). R. Bras. Ciência do Solo, v.28, p.695-712. 2004.

KONDO, R., CHILDS, C., ATKINSON, I. Opal Phytoliths of New Zealand. Manaaki Whenua Press, 1994.

MULHOLAND, S.C. Phytolith Shape Frequencies in North Dakota Grasses: A Comparison to General Patterns. Journal of Archaeological Science. 16, 489-511, 1989.

PIPERNO, D. R. Phytoliths Analysis: na archaelogical and geological perspective. San Diego: Academic Press. 1988.

OSTERRIETH, M. Rol e importancia del estudio de las biomineralizaciones en Biología, Geología y Arqueología. Curso ministrado no $7^{\text {th }}$ International Meeting on Phytolith Research, Mar del Plata., 2008.

TWISS, C. Predicted world distribution of C3 and C4 grass phytoliths, In: G. Rapp, J., Mulholand, S.C. (Eds.), Phytolith Systematics. Plenum Press, New York, 1992.

TWISS, C. Dust deposition and opal phytoliths in the Great Plains. Transactions of the Nebraska Academy of Sciences XI, 73-82, 1969. 